\title{
Plant Spacing Influences Yield and Linear Growth Rate of Sweetpotatoes Grown Hydroponically
}

\author{
D.G. Mortley', P.A. Loretan ${ }^{2}$, C.K. Bonsi ${ }^{2}$, W.A. Hi11 ${ }^{3}$, and \\ C.E. Morris ${ }^{2}$ \\ George Washington Carver Agricultural Experiment Station, Tuskegee \\ Universit ${ }_{v}$ Tuskegee, AL 36088
}

Additional index words. Ipomoea batatas, plant density, nutrient film technique

\begin{abstract}
The effects of within-channel spacings (WCS; 13, 18, $25 \mathrm{~cm}$ ) and betweenchannel spacings $(\mathrm{BCS} ; 13,25,38 \mathrm{~cm})$ on yield and linear growth rate of sweetpotatoes [Ipomoea batalas (L.) Lam.] grown by use of the nutrient film technique (NFT) were evaluated. Storage root count, fresh and dry weights, and linear growth rate, expressed as root area, declined linearly in response to decreased BCS, while fresh and dry foliage weight decreased linearly and quadratically as spacing was reduced within the growth channels. Neither linear growth rate on a canopy area basis nor the edible biomass index was significantly affected by WCS or BCS.
\end{abstract}

Data from plant-spacing experiments involving sweetpotatoes have shown that, for a designated planting period, mean total yield per hectare and yields of no. 1 grade and small roots are increased, while yields of jumbo and oversize roots are decreased, by decreasing within-row plant spacings (Anderson et al., 1945). In addition, Zimmerly (1934) found increases in mean number of storage roots per plant with increased withinrow spacings.

Sweetpotatoes have been grown hydroponically with the nutrient film technique (NFT) as part of the National Aeronautics and Space Administration's Controlled Ecological Life Support Systems (CELSS) program. Because of its foliage growth, the sweetpotato has a tendency to quickly occupy the available growing area in semi- or completely controlled environments. Therefore, amount of light, moisture, nutrients, etc. available to each plant can be affected by final plant spacing. Plant density has a pronounced effect on sweetpotato growth (Austin and Aung, 1973); however, few data are available regarding the effects of plant spacing in semi- or totally controlled environments on sweetpotato yields.

Our objective was to determine the effects of spacings of plants within and between NFT growing channels on sweetpotato storage root and foliage yields, growth rates, and edible biomass index (EBI).

Received for publication 2 Nov. 1990. Contribution no. PS 202 of the George Washington Carver Agricultural Experiment Station, NASA (Grant no. NAG10-0024) and USDA/CRSR (Grant no. ALXSP-1). We thank Ralph Prince and William Knott of the NASA/John F. Kennedy Space Center for their technical assistance. The cost of publishing this paper was defrayed in part by the payment of page charges. Under postal regulations, this paper therefore must be hereby marked advertisement solely to indicate this fact.

'Postdoctoral Research Associate.

${ }^{2}$ Associate Professor.

${ }^{3}$ Professor.
Two separate experiments were conducted in a greenhouse to evaluate the effects of plant spacing on growth and yield of sweetpotatoes using NFT. Vine cuttings $(15 \mathrm{~cm}$ long) of the breeding clone TI-155 were grown in standard rectangular Tuskegee Univ. NFT channels $(0.15 \times 0.15 \times 1.2 \mathrm{~m})$ using three within-channel spacings (WCS) $(13,18$, and $25 \mathrm{~cm}$ ) resulting in eight, six, and four plants per channel, respectively, and three between-channel spacings (BES) $(13,25$, and $38 \mathrm{~cm}$ ) with four plants per channel. Both experiments used two channels per treatment, with a $25-\mathrm{cm}$ spacing between WCS and within BCS channels. Each channel was supplied by a 30.4-liter reservoir. A modified half Hoagland (Hoagland and Arnon, 1950) solution with $1 \mathrm{~N}: 2.4 \mathrm{~K}$ ratio was used. The nutrient solution $\mathrm{pH}$ was maintained between 5.5 and 6.0 by the addition of either $\mathrm{NaOH}$ or $\mathrm{H}_{2} \mathrm{SO}_{4}$. Solutions were changed every 2 weeks and were topped with deionized water if the volume of nutrient solution fell to $\leq 8$ liters before the end of the 2 weeks. The nutrient solution was pumped from each reservoir to the high end of each channel by small submersible pumps (Teel Model 1P680A, 1/200 HP, Dayton Electric, Chicago). The channels had a $1 \%$ downward slope toward each reservoir. The nutrient solution spread across each growing channel in a thin film as it flowed back to the reservoir. Flow rate was set at 1 liter- $\min ^{-1}$ by using a bypass line back to the reservoir with a control valve. Each vine cutting was held in place by a flat-plate assembly (Morris et al., 1989) attached to the side of the channels by a flexible black/white vinyl covering. Plants were trained by tying them to vertical strings dropping $1 \mathrm{~m}$ from above each growing channel (Fig. 1).

The greenhouse ranged from 24 to $33 \mathrm{C}$ throughout the study, depending on the season and weather conditions. The daytime irradiance level varied with the season, time of day, and the weather conditions and ranged from 200 to $1700 \mu \mathrm{mol} \cdot \mathrm{m}^{-2} \cdot \mathrm{s}^{-1}$. The rela- tive humidity ranged between $60 \%$ and $95 \%$.

Plants were harvested 120 days after planting. All foliage was cut at the base of the plant, weighed fresh, dried for $48 \mathrm{~h}$ at 70C, and reweighed. A 25-g sample of one storage root from each plant was taken and dried at $70 \mathrm{C}$ for $48 \mathrm{~h}$ to determine storage root dry weight. EBI (storage root mass/total plant mass) $\times 100$ and linear growth rates (grams per square meter per day) were determined on canopy and root area bases.

Both experiments were set up as randomized complete block designs with two replications. Each experiment was repeated and the data were combined by experiments and analyzed by the General Linear Models procedure (SAS Institute, 1982). Linear and quadratic effects were partitioned from the main effect of within- and between-channel spacings.

Within-channel plant spacing effect. The number of storage roots (2.4 to 3.3) and storage root fresh (372 to $621 \mathrm{~g}$ ) and dry (66 to $128 \mathrm{~g}$ ) weights (grams per plant) were not influenced by WCS, due to the high variability in storage root fresh and dry weights (CV $=41 \%$ and $39 \%$, respectively). Foliage fresh and dry weights decreased linearly and quadratically as WCS decreased from $25 \mathrm{~cm}$ to $13 \mathrm{~cm}$ (Table 1). In both instances, however, the linear effect was stronger than that of the quadratic effect. Linear growth rate per unit area (grams per square meter per day) expressed on a canopy (4 to 8 ) and root area (23 to 28 ) basis and EBI (59\% to $72 \%$ ) was not influenced by WCS.

Between-channel plant spacing effect. The number of storage roots, storage root fresh weight, and dry weight decreased linearly in response to reduced BCS (Table 2). Foliage fresh (144 to $289 \mathrm{~g}$ ) and dry (18 to $35 \mathrm{~g}$ ) weights were not affected by BCS. Linear growth rate per unit area expressed on a canopy area basis was not influenced by BCS, although it tended to decrease in response to reduced plant spacing. However, linear growth rate on a root area basis decreased linearly as spacing between growth channels decreased from $38 \mathrm{~cm}$ to $13 \mathrm{~cm}$. Spacing did not significantly affect EBI (range $36 \%$ to $58 \%$ ).

These results show that the number of storage roots produced per plant was not significantly influenced by WCS but declined linearly in response to BCS. The fact that there was a similarity between the number of storage roots and yield per plant for the 18- and 25-cm WCS (Table 1) suggests there

Table 1. Effects of spacing within growth channels on foliage weight of TI- 155 sweetpotatoes grown with the nutrient film techniques.

\begin{tabular}{lcc}
\hline \hline & \multicolumn{2}{c}{$\begin{array}{c}\text { Foliage wt } \\
\text { (g/plant) }\end{array}$} \\
\cline { 2 - 3 } Spacing & Fresh & Dry \\
\hline 13 & 171 & 23 \\
18 & 198 & 27 \\
25 & 341 & 49 \\
Significance $^{z}$ & $\mathrm{~L}^{*} \mathrm{Q}^{*}$ & $\mathrm{~L}^{*} \mathrm{Q}^{* *}$ \\
\hline
\end{tabular}

${ }^{\mathrm{z}}$ Linear $(\mathrm{L})$, quadratic $(\mathrm{Q})$ and significant at $P=$ $0.05\left(^{*}\right)$ or $0.01\left(^{* *}\right)$. 


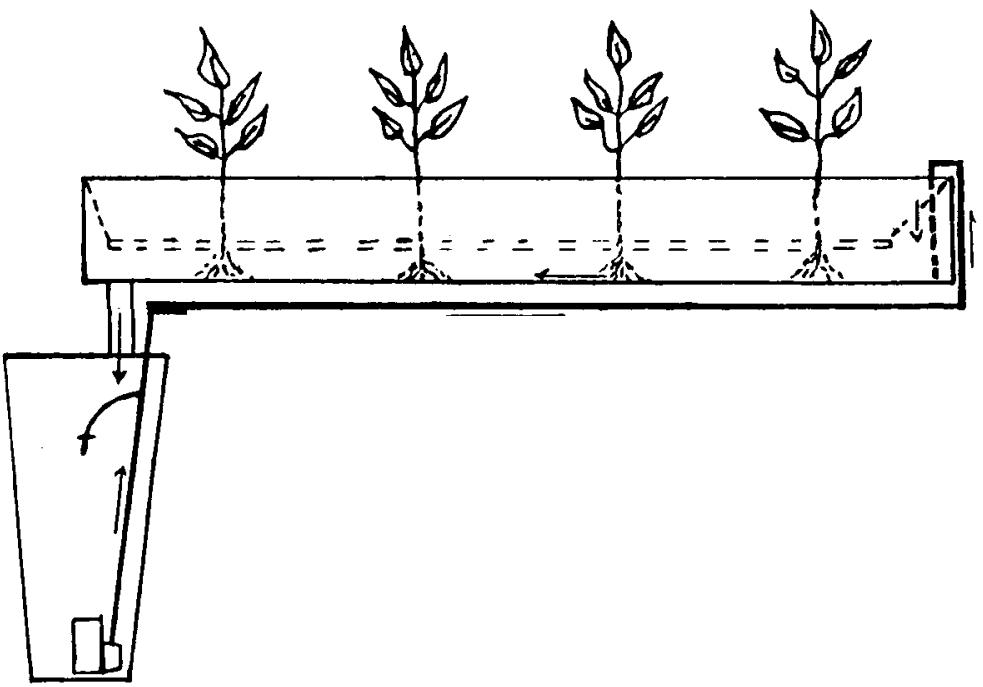

Fig. 1. Diagram of growth channel and setup of the nutrient solution circulating system. $\mathrm{R}=$ reservoir; $\mathrm{GC}=$ growth channel; $\mathrm{FP}=$ flat plate assembly; $\mathrm{B}=$ bypass line. Arrows indicate the flow of nutrient solution.

Table 2. Effects of spacing between growth channels on yield and growth rate of TI-155 sweetpotatoes grown with the nutrient film technique.

\begin{tabular}{|c|c|c|c|c|c|}
\hline \multirow[b]{2}{*}{$\begin{array}{l}\text { Spacing } \\
(\mathrm{cm})\end{array}$} & \multicolumn{3}{|c|}{ Storage root } & \multicolumn{2}{|c|}{$\begin{array}{c}\text { Linear growth rate } \\
\left(\mathrm{g} \cdot \mathrm{m}^{-2} \cdot \mathrm{day}^{-1}\right)\end{array}$} \\
\hline & No./plant & $\begin{array}{l}\text { Fresh wt } \\
\text { (g/plant) }\end{array}$ & $\begin{array}{l}\text { Dry wt } \\
\text { (g/plant) }\end{array}$ & $\begin{array}{c}\text { Canopy } \\
\text { area }\end{array}$ & $\begin{array}{c}\text { Root } \\
\text { area }\end{array}$ \\
\hline 13 & 1.5 & 124 & 19 & 1.9 & 3.4 \\
\hline 25 & 2.1 & 286 & 37 & 2.5 & 6.6 \\
\hline 38 & 3.9 & 451 & 58 & 3.0 & 10.3 \\
\hline Significance $^{z}$ & $\mathbf{L}^{*}$ & $\mathrm{~L}^{*}$ & $\mathrm{~L}^{*}$ & NS & $\mathrm{L}^{* *}$ \\
\hline
\end{tabular}

${ }^{2}$ Linear (L), quadratic (Q), and significant at $P=0.05\left({ }^{*}\right), 0.01\left({ }^{* *}\right)$, or nonsignificant (NS).

was little difference in sizes of storage roots produced between the two spacings.

Storage root fresh and dry weight on a perplant basis for all plants decreased, although not significantly, with reductions in WCS and decreased linearly in response to reduced BCS. This decrease probably occurred as a result of increased competition for light.

Yield decreases in sweetpotato associated with decreased plant spacing could be due in part to increased shading effects on "sink" establishment (Fery and Janick, 1970; Rodriguez and Lambeth, 1975). Thus, the decrease in the proportion of dry matter allocated to storage roots with decreasing plant spacing in this study, where water and nutrients were not limiting, suggests that yield may have been affected by an inadequate supply of assimilates.

We also observed that storage root fresh weight produced by the interior plants was lower in the closer WCS. The lower fresh weight of these plants was probably due to more competition for light and a smaller sur- face area for photosynthetic activity. Papadopoulos and Ormrod (1988), reported a lower net photosynthetic rate on greenhouse tomato plants grown within the row as well as lower leaflet net photosynthesis in the periphery of the canopy in response to decreased plant spacing.

Foliage fresh and dry weights also declined in response to WCS, probably due to effects of shading. Although not quantified, branching decreased as plant spacing decreased, and this was manifested in lower foliage weight. This relationship seems to be in agreement with that reported by Somda and Kays (1990), who suggested that branch formation in sweetpotato is highly plastic, responding to space available during the growing season.

Plant spacing had an opposite effect on linear growth rate calculated on the basis of canopy and root area (grams per square meter per day). For example, linear growth rate was not affected regardless of WCS. By contrast, linear growth rate expressed as canopy area was not affected by BCS, whereas when calculated on a root area basis it declined linearly in response to decreased BCS. In addition, EBI was not affected by WCS or BCS.

The linear or quadratic decrease of foliage fresh and dry weight in response to decreased WCS and linear decreases in storage root number per plant, fresh and dry weights, as well as linear growth rate on a root-area basis with reduced BCS suggest that the optimum within- and between-channel spacings may be in the range of 18 to $25 \mathrm{~cm}$ and 25 to $38 \mathrm{~cm}$, respectively.

The results of this investigation showed that yield of TI-155 sweetpotato using NFT under greenhouse conditions can be limited by availability of space as was evident from the low yields at the closer spacings. Yield in CELSS must be measured per unit time and based on an optimum use of space. Although sweetpotato leaves are edible, excess foliage is not desirable in CELSS. Maximum yield of roots per square meter may be the most important factor, even if yield per plant is not maximal.

\section{Literature Cited}

Anderson, W. S., H.L. Cochran, J.B. Edmond, O.B. Garrison, R.E. Wright, and V.R. Boswell. 1945. Regional studies of time of planting and hill spacing of sweet potatoes U.S. Dept. Agr. Circ., 72.

Austin, M.E. and L.H. Aung. 1973. Patterns of dry matter distribution during development of sweet potato (Ipomoea batatas) J. Hort. Sci. 48:11-17.

Fery, R.L. and J. Janick. 1970. Response of the tomato to population pressure. J. Amer. Soc. Hort. Sci. 95:614-624.

Hoagload, D.R. and D.I. Arnon, 1950. The waterculture method for growing plants without soil. Calif. Agr. Expt. Sta. Circ. 347.

Morns, C. E., P.A. Loretan, C.K. Bonsi, and W.A. Hill. 1989. Movable root contact pressure plate assembly for hydroponic system. U.S. Patent 4,860,490.29 Aug. 1989.

Papadopoulos, A.P. and D.P. Ormrod. 1988. Plant spacing effects on photosynthesis and transpiration of the greenhouse tomato. can. J. Plant Sci. 68:1209-1218.

Rodriguez, B.R. and V.N. Lambeth. 1975. Artificial lighting and spacing as photosynthetic and yield factors in winter greenhouse tomato culture. J. Amer. Soc. Hort. Sci. 100:694-697.

Somda, Z.C. and S.J. Kays. 1990. Sweet potato canopy architecture: Branching pattern. J. Amer. Soc. Hort. Sci. 115:33-38.

SAS Institute. 1982. SAS user's guide: Basics. SAS Institute, Inc, Cary, N.C.

Zimmerly, H.H. 1934. The effect of plant spacing on the development of the sweet potato roots. Proc. Amer. Soc. Hort. Sci. 32:494-497. 